\title{
Pelatihan Penyelesaian Soal-Soal Fisika Berorientasi Higher-Order Thinking Skills (HOTS) pada Siswa Sekolah Menengah
}

\author{
Ni Nyoman Sri Putu Verawati ${ }^{1 *}$, Hairunnisyah Sahidu ${ }^{2}$, Gunawan $^{3}$, Ahmad Busyairi ${ }^{4}$, Jannatin \\ Ardhuha $^{5}$
}

${ }^{1}$ Program Studi Pendidikan Fisika, FKIP Universitas Mataram, Mataram, Indonesia

DOI: https://doi.org/10.29303/.jpmsi.v2i2.78

Citation: Verawati, N., N., S., P., Sahidu, H., Gunawan, G., Busyairi, A., 'Ardhuha, J. 2020. Pelatihan Penyelesaian Soal-Soal Fisika Berorientasi Higher-Order Thinking Skills (HOTS) pada Siswa Sekolah Menengah. Jurnal Pengabdian Masyarakat Sains Indonesia (JPMSI). 2(2):143-146.

Article history

Received: November $01^{\text {th }} 2020$ Revised: November $15^{\text {th }} 2020$

Accepted: November $23^{\text {th }} 2020$

*Corresponding Author: Ni Nyoman Sri Putu Verawati, FKIP Universitas Mataram, Mataram, Indonesia; Email:

veyra@unram.ac.id

\section{Pendahuluan}

Tolak ukur kemajuan suatu bangsa salah satunya adalah kualitas pendidikannya (Megawati dkk., 2020), dan salah satu aspek penting kualitas pendidikan yaitu siswa yang dapat bersaing secara global dan mampu memecahkan permasalahan dalam kehidupan sehari-hari. Ditinjau dari daya saing secara global, kualitas pendidikan Indonesia nampaknya masih rendah. Hasil studi Programme for International Student Assessment (PISA) yang diselenggarakan oleh Organization for Economic Cooperation and Development (OECD) pada tahun 2015, Indonesia menduduki peringkat 62 dari 70 negara (OECD, 2017). Indikator asesmen PISA antara lain kemampuan siswa dalam memecahkan
Abstrak: Permasalahan utama siswa pada umumnya adalah siswa kurang mampu merikal fisika yang berorientasi HOTS. Berdasarkan masalah ini, melalui kuk pelatihan penyelesaian soal-soal fisika yang berorientasi pada HOTS adalah SMAK Kesuma Mataram dengan kelompok mitra yang terlibat dalam kegiatan sebanyak 13 (tigabelas) siswa kelas XII IPA. Sesuai dengan prioritas permasalahan yang ada, maka solusi yang direncanakan, yaitu melalui proses pelatihan dan pendampingan. Solusi yang dimaksud pada implementasinya melalui; (a) In Service Training (IST), yaitu pelatihan penyelesaian soal-soal fisika yang berorientasi pada HOTS, dan (b) On Service Training (OST), yaitu penyajian soal-soal fisika yang erorientasi pada HOTS dan meminta siswa menyelesaikannya serta mengevaluasi siswa dalam menyelesaikan soal-soal fisika yang berorientasi HOTS tersebut. (1) persiapan yang dilakukan, kegiatan PKM dilaksanakan dengan mode daring Service Traing (OST). Kegian PKM In Service Trining (IST) dan On yang diharapkan serta mendapat respon positif dari pihak sekolah mitra. Kedepan diharapkan dapat dilakukan kegiatan serupa di sekolah lain karena siswa sangat membutuhkan pelatihan yang terkait dengan penyelesaian soal-soal fisika berorientasi higher-order thinking skills (HOTS).

Kata kunci: Penyelesaian Soal Fisika, Higher-Order Thinking Skills, In Service Training, On Service Training.

masalah dan keterampilan berpikir tingkat tinggi (higher-order thinking skill) atau yang biasa disebut dengan HOTS.

Dewasa ini berbagai studi selain PISA melaporkan bahwa untuk menghadapi tantangan dan perkembangan abad modern ini diperlukan bukan sekedar pengetahuan konseptual semata, melainkan keterampilan mengaplikasikan pengetahuan dan berbagai keterampilan berpikir. Terkait dengan hal tersebut, Partnership for 21st Century Skills merumuskan beberapa keterampilan yang selanjutnya disebut sebagai kecakapan abad 21 atau sering disebut 21 st Century Skills. Beberapa keterampilan yang termuat dalam kecakapan abad 21 tersebut di antaranya yaitu kreativitas, 
Verawati et al, Jurnal Pengabdian Masyarakat Sains Indonesia 2020, 2 (2):143-145. DOI : https://doi.org/10.29303/jpmsi.v2i2.78

keterampilan berpikir kritis dan pemecahan masalah. Keterampilan-keterampilan tersebut sering juga dikenal sebagai cakupan dari keterampilan berpikir tingkat tinggi (HOTS). Tuntutan akan perlunya keterampilan-keterampilan tersebut berimplikasi pada perlunya peningkatan kualitas penyelenggaraan pendidikan.

Peningkatan kualitas penyelenggaran pendidikan ditandai dengan adanya reformasi kurikulum. Sebagai contoh, di Amerika Serikat kurikulum matematika untuk sekolah menengah secara eksplisit telah memuat pemecahan masalah, penalaran, komunikasi, koneksi, dan representasi sebagai bagian dari cakupan kurikulum (NCTM, 2000). Begitupun dengan Finlandia yang menempatkan keterampilan berpikir tingkat tinggi sebagai bagian dari kurikulum sekolah menengah, yaitu melalui muatan kurikulum "keterampilan berpikir dan metode berpikir" (thinking skills and methods) (Finnish National Board of Education, 2003). Di Indonesia muatan kurikulum yang berorientasi pada pengembangan berbagai keterampilan berpikir, khususnya keterampilan berpikir tingkat tinggi mulai diperhatikan dengan diterapkannya Kurikulum 2013. Dengan demikian keterampilan berpikir tingkat tinggi atau higherorder thinking skills (HOTS) menjadi tujuan utama dalam proses pembelajaran. Namun demikian, pembelajaran sains di Indonesia pada kenyataannya masih banyak yang semata berorientasi pada upaya mengembangkan dan menguji daya ingat siswa sehingga kemampuan berpikir siswa direduksi dan sekedar dipahami sebagai kemampuan untuk mengingat.

Wawancara mendalam (indept interview) telah dilakukan tim pengusul pengabdian dengan guru mata pelajaran fisika di SMAK Kesuma Mataram terkait dengan kemampuan berpikir tingkat tinggi siswa. Dari hasil wawancara diketahui bahwa walaupun kurikulum 2013 telah diimplementasi namun ketika evaluasi siswa masih kesulitan dalam menyelesaikan soal-soal yang membutuhkan keterampilan berpikir tingkat tinggi. Di satu sisi guru harus menyelesaikan materi ajar dalam satu semester yang sangat padat, sehingga sudah terkondisi proses evaluasi hanya berdasarkan pada soal-soal yang terdapat pada buku paket siswa. Oleh karena itu, perlu dilakukan pelatihan kepada siswa agar siswa terbiasa menyelesaikan soal-soal fisika yang berorientasi pada HOTS.
e-ISSN : 2715-2537

p-ISSN : 2715-2545

Mitra kegiatan pengabdian kepada masyarakat ini adalah SMAK Kesuma Mataram, dengan kelompok mitra para siswa yang tergabung dalam kelas IPA. Permasalahan utama siswa adalah kurang mampu menyelesaikan soal-soal fisika yang berorientasi HOTS. Berdasarkan analisis masalah ini, maka perlu dilakukan pelatihan penyelesaian soal-soal fisika yang berorientasi pada HOTS melalui kegiatan pengabdian kepada masyarakat (PKM).

\section{Metode}

Sesuai dengan prioritas permasalahan yang ada, maka metode pendekatan yang digunakan untuk menyelesaikan permasalahan yang ada, yaitu dengan metode pelatihan melalui In Service Training (IST) dan On Service Training (OST). Melalui IST siswa diberikan pelatihan penyelesaian soal-soal fisika yang berorientasi pada HOTS. IST dilakukan dengan pendekatan andragogis yang mengedepankan diskusi dan tanya jawab dengan harapan dapat meningkatkan kompetensi siswa dalam menyelesaikan soal-soal fisika yang berorientasi pada HOTS. Melalui OST siswa dievaluasi kemampuannya dalam menyelesaikan soal-soal fisika yang berorientasi pada HOTS. OST membuka peluang diskusi sekiranya siswa masih belum kompeten dalam menyelesaikan soal-soal fisika yang berorientasi pada HOTS. Kegiatan dilaksanakan pada tanggal 8 Oktober 2020 bertempat di SMAK Kesuma Mataram, jalan Pejanggik 110 Cakranegara - Kota Mataram. Kegiatan PKM dilaksanakan oleh 5 (lima) orang tim pelaksana dari unsur dosen Program Studi Pendidikan Fisika FKIP UNRAM, melibatkan 13 (tiga belas) siswa kelas XII IPA serta 1 (satu) orang guru pendamping.

Untuk mencapai target luaran kegiatan pengabdian kepada masyarakat (PKM), maka tahapan implementasinya yaitu; a) tahap persiapan, b) tahap pelatihan melalui In Service Training (IST) dan On Service Training (OST), dan c) tahap monitoring dan evaluasi. Kegiatan evaluasi dilakukan untuk memantau sejauh mana kegiatan pengabdian mampu mencapai sasaran dan menghasilkan luaran seperti yang direncanakan. Langkah evaluasi yang dilakukan, yaitu; evaluasi rencana, evaluasi proses, dan evaluasi hasil. Kegiatan evaluasi kegiatan pengabdian ini juga dimaksudkan untuk mengevaluasi kegiatan secara utuh dan menjadi pijakan bagi tim pengabdian 
Verawati et al, Jurnal Pengabdian Masyarakat Sains Indonesia 2020, 2 (2):143-145. DOI : https://doi.org/10.29303/jpmsi.v2i2.78

untuk melaksanakan kegiatan serupa di masa-masa mendatang. Selanjutnya, keberlanjutan program di lapangan setelah kegiatan pengabdian selesai dilaksanakan, yaitu dengan membangun kerjasama kemitraan jangka panjang dengan sekolah yang melibatkan SDM sekolah yang lainnya. Melalui kerjasamaa kemitraan akan dilakukan pendampingan intensif kepada SDM yang ada, mengadakan workshop, seminar-seminar dan sejenisnya.

\section{Hasil dan Pembahasan}

Program pengabdian pada masyarakat
$(\mathrm{PKM})$ kemitraan dengan tema "Pelatihan Penyelesaian Soal-Soal Fisika Berorientasi HigherOrder Thinking Skills (HOTS) pada Siswa Sekolah Menengah" telah dilaksanakan dengan mitra kegiatan, yaitu SMAK Kesuma Mataram. Pelaksanaan kegiatan PKM pada tahap implementasinya dijelaskan sebagai berikut.

\section{Tahap persiapan}

Kegiatan yang dilakukan pada tahapan ini meliputi: menyusun ToR (Term of Reference), identifikasi calon mitra, pertemuan internal tim pelaksana, pertemuan eksternal tim dengan mitra untuk menentukan jadwal pelaksanaan, tempat, dan materi, serta pengurusan izin melaksanakan kegiatan pengabdian. Kegiatan PKM ini awalnya direncanakan dilaksanakan dengan mode tatap muka, namun seperti diketahui akibat wabah Covid-19 kegiatan tatap muka dengan siswa tidak dimungkinkan untuk dilaksanakan. Oleh karena itu, berdasarkan hasil diskusi tim PKM dengan pihak sekolah akhirnya pelaksanaan kegiatan PKM tentang pelatihan penyelesaian soal-soal fisika berorientasi higher-order thinking skills (HOTS)
e-ISSN : 2715-2537

p-ISSN : 2715-2545

pada siswa dilaksanakan dengan mode daring (online) menggunakan platform zoom meeting. Pada prosesnya, tim pelaksana kegiatan PKM berada di lokasi kegiatan sementara siswa peserta pelatihan mengikuti program kegiatan dari rumah.

\section{Tahap pelatihan melalui In Service Training (IST) dan On Service Training (OST).}

Kegiatan dilaksanakan pada tanggal 8 Oktober 2020 bertempat di SMAK Kesuma Mataram, jalan Pejanggik 110 Cakranegara - Kota Mataram. Kegiatan PKM dilaksanakan oleh 5 (lima) orang tim pelaksana dari unsur dosen Program Studi Pendidikan Fisika FKIP UNRAM, melibatkan 13 (tiga belas) siswa kelas XII IPA serta 1 (satu) orang guru pendamping. Pelaksanaan kegiatan PKM melalui In Service Training (IST) dan On Service Training (OST). Melalui mekanisme IST, siswa diberikan pelatihan penyelesaian soal-soal fisika yang berorientasi pada HOTS. Penyampaian materi dilakukan secara paralel oleh tim pelaksana kegiatan dimana IST dilakukan dengan pendekatan andragogis yang mengedepankan diskusi dan tanya jawab yang menekankan pada peningkatan kompetensi siswa dalam menyelesaikan soal-soal fisika yang berorientasi pada HOTS. Setelah IST selanjutnya kegiatan PKM dilaksnakan melalui mekanisme On Service Training (OST). Melalui OST siswa dievaluasi kemampuannya dalam menyelesaikan soal-soal fisika yang berorientasi pada HOTS. OST membuka peluang diskusi sekiranya siswa masih belum kompeten dalam menyelesaikan soal-soal fisika yang berorientasi pada HOTS. Kegiatan IST dan OST dilaksanakan selama 1 hari penuh mulai pukul 08.00 WITA sampai dengan pukul 16.00 WITA.

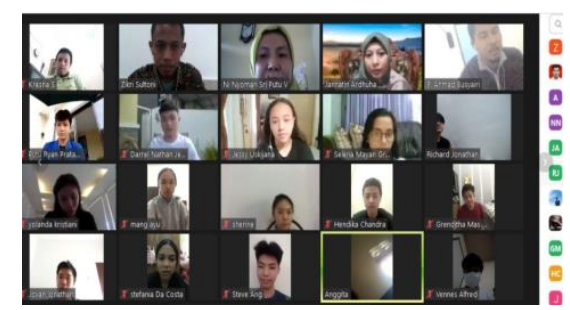

\section{Tahap monitoring dan evaluasi}

Kegiatan pada tahapan ini dimaksudkan untuk mendeteksi dan mengevaluasi keseluruhan kegiatan pengabdian kepada masyarakat (PKM)
Gambar 1. Kegiatan PKM melalui Zoom Meeting
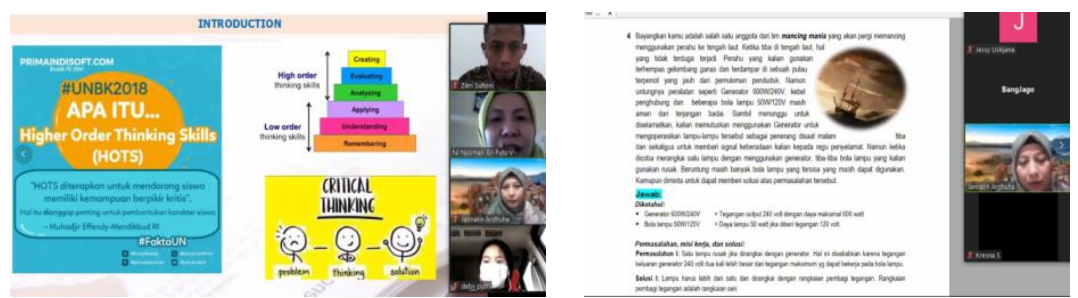

sehingga dapat diketahui hasil, teridentifikasi kendala yang muncul, faktor yang mendukung dan menghambat serta solusi pemecahanya. Secara umum, pelaksanaan kegiatan berjalan dengan 
Verawati et al, Jurnal Pengabdian Masyarakat Sains Indonesia 2020, 2 (2):143-145. DOI : https://doi.org/10.29303/jpmsi.v2i2.78

lancar di tengah keterbatasan ruang dan waktu karena wabah Covid-19 yang terjadi di luar kendali. Kelancaran pelaksanaan kegiatan karena tersedianya media online dalam hal ini zoom meeting yang dimanfaatkan tim pelaksana dalam kegiatan pengabdian ini. Kendala yang muncul ketika pelaksanaan kegiatan PKM yaitu aksesabilitas, artinya ketika pelaksanaan kegiatan (IST dan IST) sempat beberapa kali akses internet terputus pada beberapa siswa yang mengikuti kegiatan PKM dari rumah masing-masing. Ini termasuk kendala sekaligus faktor penghambat kegiatan PKM ini. Permasalahan akses internet ini diluar kendali tim pelaksana PKM, namun yang dilakukan tim pada saat itu adalah mengulang kembali atau memaparkan kembali materi yang disampaikan sebelumnya sehingga terjadi pemerataan pengetahuan dari setiap siswa yang mengikuti kegiatan PKM ini. Kegiatan ini mendapat kesan positif dari pihak sekolah, setidaknya karena dua faktor. Pertama, pelatihan soal-soal yang berorientasi HOTS belum pernah dilakukan di sekolah mitra padahal ini sangat dibutuhkan siswa, sehingga tema pelatihan ini dianggap baru bagi pihak sekolah. Kedua, kegiatan pelatihan ini mewarnai kegiatan sekolah di tengah pandemi Covid-19, untuk dimaklumi bahwa kegiatan di sekolah selain program pembelajaran daring hampir vakum, sehingga kegiatan ini dianggap bernilai di tengah pandemi Covid-19 yang melanda.

\section{Kesimpulan}

Telah dilaksanakan program pengabdian pada masyarakat (PKM) kemitraan dengan tema "Pelatihan Penyelesaian Soal-Soal Fisika Berorientasi Higher-Order Thinking Skills (HOTS) pada Siswa Sekolah Menengah" di SMAK Kesuma Mataram. Dengan persiapan yang dilakukan, kegiatan PKM dilaksanakan dengan mode daring (online) memanfaatkan media zoom meeting melalui In Service Training (IST) dan On Service Training (OST). Kegiatan berjalan dengan baik sesuai dengan tujuan yang diharapkan serta mendapat respon positif dari pihak sekolah mitra.

\section{Saran}

Penulis berharap ke depannya dapat dilakukan kegiatan serupa di sekolah lain karena
e-ISSN : 2715-2537

p-ISSN : 2715-2545

siswa sangat membutuhkan pelatihan yang terkait dengan penyelesaian soal-soal fisika berorientasi higher-order thinking skills (HOTS).

\section{Ucapan Terima Kasih}

Terima kasih kami ucapkan kepada Universitas Mataram dan LPPM yang telah membiayai kegiatan ini dan juga kepada SMAK Kesuma Mataram serta semua pihak yang telah membantu dan berpartisipasi sehingga kegiatan pengabdian ini terlaksana dengan baik dan lancar.

\section{Daftar Pustaka}

Megawati, Wardani, A. K., \& Hartatiana. (2020). Kemampuan berpikir tingkat tinggi siswa SMP dalam menyelesaikan soal matematika model PISA. Jurnal Pendidikan Matematika, 14(1): 15-24

NCTM. (2000). Principles and standard for school mathematics. Reston, VA: The National Council of Teacher Mathematics, Inc.

Organisation for Economic Co-operation and Development. (2017). PISA 2015 results: Collaborative problem solving (Volume V). Paris: OECD Publishing

Partnership for 21st Century Skills. (2002). Learning for the 21st century: A report and mile guide for 21 st century skills. Tucson, AZ: Author

PISA. (2015). PISA Results: Excellence and equity in education. Acces from http://www.oecd.org/education/pisa-2015results-volume-i-9789264266490-en.htm 